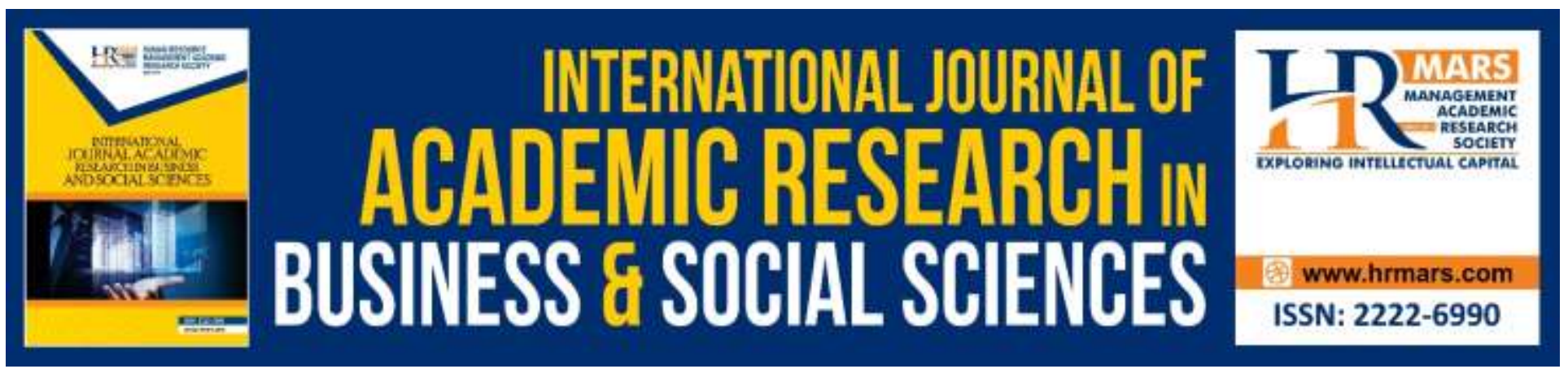

\title{
A Review of the Economic Presence of China in Namibia
}

\section{Natangwe Simon Ndawana Hamunyela, Junhui Guo, QianQian Chen}

To Link this Article: http://dx.doi.org/10.6007/IJARBSS/v10-i6/7311

DOI:10.6007/IJARBSS/v10-i6/7311

Received: 21 April 2020, Revised: 25 May 2020, Accepted: 14 June 2020

Published Online: 25 June 2020

In-Text Citation: (Hamunyela et al., 2020)

To Cite this Article: Hamunyela, N. S. N., Guo, J., \& Chen, Q. (2020). A Review of the Economic Presence of China in Namibia. International Journal of Academic Research in Business and Social Sciences, 10(6), 406-418.

Copyright: @ 2020 The Author(s)

Published by Human Resource Management Academic Research Society (www.hrmars.com)

This article is published under the Creative Commons Attribution (CC BY 4.0) license. Anyone may reproduce, distribute, translate and create derivative works of this article (for both commercial and non-commercial purposes), subject to full attribution to the original publication and authors. The full terms of this license may be seen

at: $\underline{\text { http://creativecommons.org/licences/by/4.0/legalcode }}$

\section{Vol. 10, No. 6, 2020, Pg. 406 - 418}

Full Terms \& Conditions of access and use can be found at http://hrmars.com/index.php/pages/detail/publication-ethics 


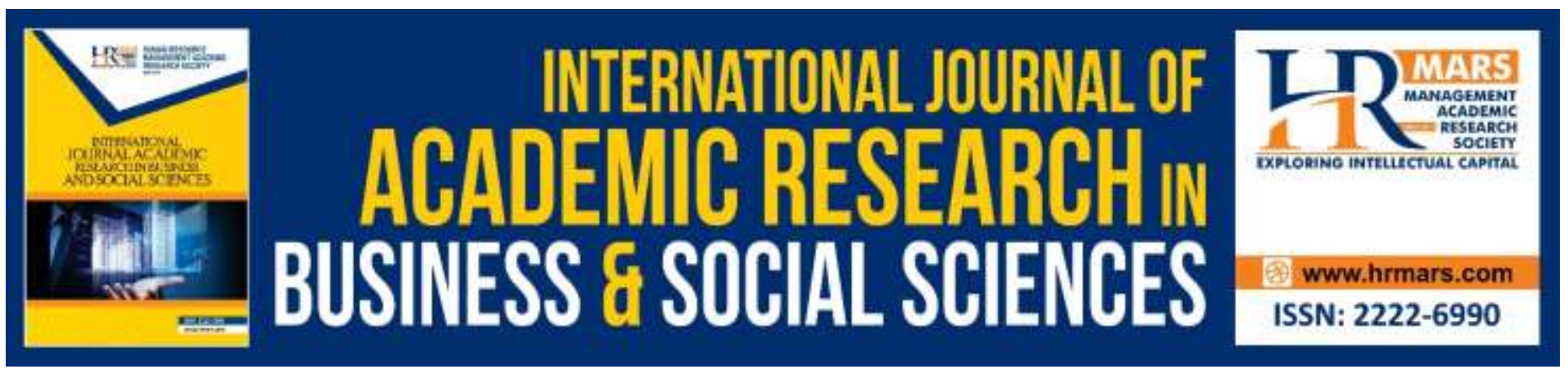

\title{
A Review of the Economic Presence of China in Namibia
}

\section{Natangwe Simon Ndawana Hamunyela, Junhui Guo, QianQian Chen}

School of Economics and Management, Zhejiang University of Science and Technology, Hangzhou China

Email: nsnhamunyela@hotmail.com, lissiechen@gmail.com

\begin{abstract}
African countries in recent years have had many engagements with China at different levels. A growth in this relationship has raised a lot of questions in the minds of not only citizens, but scholars as well. Namibia is no exception. Namibia, a country with a very low population density, has within recent years seen the influx of Chinese at every level, and in almost every sector of the economy. The Chinese are in Namibia for one of many different reasons, and this review conveys one of those many reasons; economically. This review focuses on exploring the presence of Chinese firms and shops in the construction, mining, retail and wholesale industry. The article further raises some critical issues which are worthy of empirical assessment.
\end{abstract}

Keywords: Retail, Construction, Mining, Manufacturing Sector.

\section{Introduction}

The presence of China in Namibia has gradually crafted, at the governmental level, an affirmative Sino-Namibian relation. Per the officials of the Namibian government, this partnership is one that is beneficial as far as the economic development of the country is concerned. However, the relationship between these two countries is not confined at the national level, it cascades to the daily activities of Namibian nationals. The swelling of Chinese immigrants and firms in Namibia has yielded non-state actor opinions regarding the Chinese business operations, non-state actors and the relationship between the two countries. At different levels within the Namibian society, subjective views are expressed about the presence of the Chinese and these views are as a result of the different interactions at varied degrees these Namibians have with the Chinese.

Dobler citing Beäutigam (2003) the sprung of industrialization as evidenced in the South Eastern part of Asia has made it possible for Chinese firms doing extremely well to move into other markets or diversify production and this is what is being experienced in Namibia. Dobler asserted the Chinese firms in Namibia take on hybrid nature, consisting of construction and retailing. Taking a retrospective look at the focus of Chinese firms during the primary years after independence in Namibia, trading centered on such items as small electronics, shoes, toasters, clothes, toys and the likes. Fast forward 
to recent years, the majority of national projects, constructions, and government deals are dominated by the Chinese. Most of the Namibian government facilities, such as roads, stadia and the like are financed and constructed by the Chinese (Yan, 2006). According to the Namibia Press Agency, the project to construct the State House was financed and constructed by the Chinese with the government of China providing a N\$50 million loan for the project. According to Sasman (2007), within a space of four years, twenty agreements were signed between the two countries. Further, the presence of China in Namibia is not limited to just the retail and construction sectors. Their presence is sublimely seen in the banking sector as well. The Industrial and Commercial Bank of China, one of the primary and well grounded financial institutions in China, is known to have secured twenty percent share in Namibian Standard Bank (Kakololo, 2007).

A mixed perception surrounds the economic and business activities of the Chinese in Namibia. In an experiment conducted by Bongiorni in 2005 in the United States, Bongiorni sought to live without any Chinese made product for a year. He realized it was possible to live without a Chinese product for a year, however, impossible to do so forever. This kind of reflects the economic relationship between China and Namibia. One key finding in the experiment was that Bongiorni spent \$70 on a tennis shoe for the son within that one year period. Contrary, Bongiorni would have spent $\$ 10-\$ 15$ for the same shoe made in China. Such quandary is what the people of Namibia are currently encountering. The views on the ground do not entirely support or reject the economic relationship between Namibia and China. The layman in Namibia enjoys the relatively cheap products from China, local businesses and other foreign investors complain of unfair competition, and labor groups complain of Chinese firms ignoring the Namibian workforce. With this backdrop, the current review will explore the economic presence of the Chinese in some key sectors of the Namibian economy. Considering the growing presence of the Chinese in Namibia, both at the institutional and individual level, different scholars have sought to explore the impacts of their presence. The objectives of this review are to:

1. Reviews a number of studies in relation to the economic activities the Chinese undertake in Namibia.

2. Explore Chinese firms and individuals within the manufacturing, construction, and retail sectors.

3. Ascertain the losers and those gaining with the sectors of Chinese operations

4. Assess the impacts of the activities of the Chinese on the mining, construction, retail and wholesale, and manufacturing sectors

The review begins with discussions on the cooperative arrangements between China and Namibia, and goes ahead to discuss economic activities of the Chinese within the thematic areas. Further, the review explores the losers and benefactors in these economic activities and finally concludes.

\section{China-Namibia Collaborations}

The relation between China and Namibia dates decades back. During Namibia's battle for independence, China is known to be one of the nations that provided support to Namibia. After independence, China became one of the first nations to build a diplomatic collaboration with Namibia. This happened not later than the day after Namibia attained independence. Proceeding from there, both countries have experienced relatively cordial collaborations in different sectors, prominent among them is in the construction industry. The government of China in 2005 offered a tourism destination status to Namibia when the Namibian President visited China. Two years after, 
INTERNATIONAL JOURNAL OF ACADEMIC RESEARCH IN BUSINESS AND SOCIAL SCIENCES Vol. 10, No. 6, June, 2020, E-ISSN: 2222-6990 @ 2020 HRMARS

the Chinese President paid a visit to Namibia during which the initial tourism status granted was formalized. The diplomatic collaboration between China and Namibia has further encompass exchange of knowledge in relation to economic management and political issues, which has seen government officials of both nations at a roundtable discussion of matters common to both countries. Mutual corporations have been built, spanning from trade, politics, education, technology, economic, health, and the like.

China has been the main reliable supplier of technology, and agro equipment and projects for the Green Scheme Project of Namibia. These provisions have come at a competitive price. A further step is being taken to establish and assemble a manufacturing hub in Namibia for agro equipment. This is meant to feed neighboring markets such as Zambia, Congo, Angola, and Botswana. The objective of the Green Scheme Project is to improve agro irrigation and infrastructure for horticulture. The government asserts the project is geared towards the enhancement of the economic and social wellbeing of rural areas in Namibia. Still in the agro sector, some of the facilities gaining the attention of China are the improvement of abattoirs to enhance the standard of meat exported by Namibia.

The government of Namibia is receiving the support of China in its attempt to develop its rural communities by sponsoring entrepreneurs in the rural areas of Namibia interact with Chinese entrepreneurs and enhance their skills and knowledge. Further, through the two main initiatives of the government of Namibia (empowerment of the San community for the household food security and food/cash for work program), the Chinese government provides assistance in the form of equipment and materials for rural development. Among some of the provisions given under these programs are: construction of roads, building of primary schools, extension of pipelines, building sports facilities, construction of affordable houses, building of town halls, and many other projects.

China is not only engaged with Namibia in the field of agriculture, but also in the educational sector, where their assistance to Namibia has come in the form of support for provision of quality education. Namibia aims to enhance the standard of education, introduce technology in its higher educational institutions, improve vocational training, introduce innovative systems throughout the stages of education, and enhancement of educational management. The government of China has assisted Namibia in these programs through the creation of the Faculty of Engineering at the University of Namibia, education and exchange of knowledge in the area of human resource development in agriculture, aqua-culture, manufacturing, processing of agricultural products, movie and video production technology and laboratory equipment for the testing of aqua-culture products.

In the mining sector, China is providing assistance to Namibia in their effort to build their capacity in the production of energy and mining via education opportunities granted to Namibians to study programs in these domains at both the bachelors and graduate level. Some of these programs include Mining Engineering, Nuclear Physics, Geology, Electrical Engineering, and Petroleum Engineering. The two countries have been involved in a number of joint ventures within the domains of small scale mining, production of cement, reprocessing of railing dumps, cutting and polishing of dimension stones, processing of copper for the production of wires, cables, robs, tubes and plates for industrial use, exploration of gas and oil, production of power system components, manufacturing and assembling of solar photovoltaic and solar thermal devices, and micro-hydro power projects. 
INTERNATIONAL JOURNAL OF ACADEMIC RESEARCH IN BUSINESS AND SOCIAL SCIENCES Vol. 10, No. 6, June, 2020, E-ISSN: 2222-6990 @ 2020 HRMARS

Further, the Chinese are heavily involved in the Namibian government's projects geared towards renovation and improvement of its road and railway systems. China is also supporting the facelift being given to the Walvis Bay port.

There has also been collaboration between Telecom Namibia and Chinese equipment supplier, Haui, in the rollout of ADSL and CDMA technology to expedite communication across the country. With the technology that comes with CDMA, clients are able to enjoy mobility when using internet and voice communication. ADSL is a high bandwidth technology system that can be deployed using the existing copper wires to homes and offices.

The preceding projects and activities have been at the center of the collaboration between China and Namibia. For the purpose of this review, China's economic engagement across three sectors, retail, construction, and mining, will be discussed.

\section{Chinese Economic Engagement in Namibia \\ Retail}

Chinese economic activities started off most visibly in the retail sector and major construction works. During the first decade after independence, a countrywide net of Chinese trading shops started to mushroom. These reminded of the 'native shops' of earlier times, when (white) traders offered simple consumer goods to the African population even in remote areas (Namibia's population of now some 2.5 million people occupy some 825,000 square kilometres of mainly semi-arid and arid land). A database of the Ministry of Trade and Industry listed in 2009 more than 500 registered Chinese shops (Jauch, 2009). Chinese shop-owners and shopkeepers, operating on a more modest scale elsewhere, are coming mainly from Fujian. They seem well connected and organized, but often have no proper permits to run their business and depend on bribing officials to avoid deportation (Melber, 2019).

Still, the largest proportion of the perhaps 6000 Chinese people living in Namibia has come as traders. It is difficult to say how many 'China shops' there are in Namibia today. It is approximated there are about 1500 Chinese shops in Namibia, but this number may be wildly off. In Oshikango, for example, there were approximately 22 Chinese-owned shops in 2004, 75 in 2006, around 120 in 2008 and no fewer than 285 in 2012 (Dobler, 2017). Around two to four Chinese migrants are associated with an average shop - as owners, family members or assistants.

Most Chinese-owned shops sell relatively cheap consumer goods: clothes, shoes, cooking ware, cheaper electronics, often counterfeit perfumes or other branded goods. Some do business in small towns and villages where such goods were not previously available; others supply informal traders in the bigger towns or, as in the case of Oshikango, sell wholesale to neighboring countries. Their main asset is their ability to bridge markets: to buy goods in China and to sell them in Namibia. Unlike most Namibian traders, they feel at home in the Chinese wholesale markets or factories; they speak the language, know the politics and are capable to smooth the goods' way overseas. Their advantage is greatest where informal arrangements increase trade gains. Many Chinese traders are much more adept than Namibians doing business in China, obtaining invoices and export papers that only show a fraction of the goods' real price, which lowers their tax burden and creates unregistered foreign currency income. This - together with hard work, family labor and often enough self-exploitation enables Chinese migrants to offer goods at lower prices than Namibian competitors. (Dobler, 2017). 
INTERNATIONAL JOURNAL OF ACADEMIC RESEARCH IN BUSINESS AND SOCIAL SCIENCES Vol. 10, No. 6, June, 2020, E-ISSN: 2222-6990 @ 2020 HRMARS

\section{Construction Sector}

Namibia is one of the countries with a lower population density in the world; Mongolia and Greenland happen to have the lowest density. The population of approximately 2.5 million is scattered across an area of $823680 \mathrm{~km} 2$, resulting in a population density of 2.8 persons per $\mathrm{km}^{2}$. This has obvious repercussions for the provision and cost of infrastructure. Irrespective of how vast the nation is, the country's infrastructure performs relatively well in the World Economic Forum's Global Competitiveness Reports. Namibia was ranked 45th out of 137 nations in the 2017-2018 report for the quality of its overall infrastructure, appreciably higher for quality of roads and ports (Santos, 2018).

Firms from China have managed to have under their control a considerable portion of works in the public sector of Namibia and have secured access to large parts of the construction industry, dwarfing competition for state tenders for office buildings, roads, railways, harbor and airport upgrades. Continued high unemployment and the gross disparities in income distribution among Namibians soon contributed to the build-up of anti-Chinese sentiments among ordinary people. The massive presence of Chinese, not least in the construction sector with large-scale projects under state tenders, resulted for the first time in public criticism by the National Union of Namibian Workers (NUNW), which is affiliated with SWAPO and largely loyal to government policies.

The presence of Chinese firms such as New Era Investment, China Jiangxe, China Zhengtai, and the like has caused bewilderment among the local construction sector, which is openly dissatisfied with what is alleged to be preferential treatment accorded to Chinese construction companies. Stateowned enterprises have often brought in privately owned Chinese companies as subcontractors who could thus make their market entry in the shadow of an established and well-financed corporation. In other cases, local managers of internationally operating Chinese companies have started their own construction companies in Namibia, sometimes together with a Namibian shareholder who bring in local connections and credibility (Dobler, 2017).

To detail just some of the standout projects recently built by contractors from China: the AntiCorruption Commission office, the new State House, Command and staff college, office complex for former President Nujoma, Auditor General head office, headquarters for the Ministries of Lands and Resettlement, Ministry of Finance, Ministry of Gender Equality and Child Welfare, Council of Traditional Leaders head office, Motor Vehicle Accident Fund, Directorate of Civil Aviation, naval base, Helao Nafidi Town Council building, government hangar complex, Namibian Institute of Public Administration and Management, Katima Mulilo Magistrates Court, classrooms for the University of Namibia in Windhoek and Ongwediva, schools, Katutura Magistrate Court, state hospitals in Oshakati, Okakarara, Katima Mulilo and Ekamba, Omuthiya Police headquarters, headquarters for the Southern African Customs Union, Oshakati High Court, UN organisations in Namibia and the upgrading of Eros and possibly soon of Hosea Kutako International Airports. Other construction works include the completed road rehabilitation from Windhoek to Okahandja, from Oshakati to Ongwediva, from Omafo to Outapi, from Omakange to Ruacana, from Okahandja to Karibib, from Tsumeb to Katwitwe (in joint ventures) - all in all, more than 670 kilometres at a cost of about N\$3.5 million per kilometre. Discussions are ongoing about the construction of a new railway line from Tsumeb to Walvis Bay and an upgrade of the roads from Walvis Bay via Khorixas to the Angolan border in Oshikango, and from Windhoek to Hosea Kutako Airport. (Dobler, 2017). Table 1.0 shows a list of some of the projects undertaken by Chinese firms. 
INTERNATIONAL JOURNAL OF ACADEMIC RESEARCH IN BUSINESS AND SOCIAL SCIENCES

Vol. 10, No. 6, June, 2020, E-ISSN: 2222-6990 @ 2020 HRMARS

Table 1.0: Some Construction Works by Chinese Firms in Namibia

\begin{tabular}{l|l}
\hline Project & City \\
\hline South West African People's Organisation & Katutura \\
(SWAPO) Party headquarters) & Windhoek \\
Supreme Court & Outapi \\
Regional Council building & Zambezi \\
Regional Council building & Rundu \\
Regional Council building & Auasblick \\
Presidential office & Auasblick \\
Presidential residence & Windhoek \\
Police and Prison Training College & Otjomuise \\
Otjomuise Police Station & Otjinene \\
Otjinene Magistrate's Court & Omuthiya \\
Oshikoto Police Regional Headquaters & Oshakati \\
Oshakati High Court & Omuthiya \\
Omuthiya Police Station & Windhoek \\
National Police headquarters &
\end{tabular}

Source: The Heritage Foundation (2020)

This is evidence that a lot of the contracts are awarded to Chinese firms with less consideration given to local contractors. This could partly be due to the fact that funds for almost all these projects are provided by the Chinese as such the suspicion that their contractors be given the projector to be executed is a part of the deal. If the few projects enumerated in this review are to be considered, it would not be out of place to say the presence of Chinese within the construction industry is enormous. Additionally, despite proposals by Niikondo and Coeztee (2008) for local companies to form joint ventures in order not only to fend of competition, but also to grow their capacities, statistics indicate that the local companies are not heeding this call as there are only a few cases of these joint projects (Tyitende, 2015)

\section{Mining}

According to Melber (2019), mining operations with direct Chinese involvement considerably increased in recent years. Eastern China Non-Ferrous Metals Investment Holdings, the investment arm of the East China Mineral Exploration and Development Bureau, announced in early December 2011 the discovery of 2 billion tons of iron ore in the Kunene region and plans to open an iron mine and steel plant with an annual production of 5 million tons. Melber noted that Chinese investments were also announced towards the end of 2012 in the Omitiomire copper mine deposit 120 km north east of Windhoek. In early December 2011, the wheeling and dealing around the ownership of Swakop Uranium, which controlled one of the largest known uranium deposits of the world at Husab, paved the way for further Chinese ownership through a takeover of Kalahari Minerals by China Guangdong Nuclear Power Corp in a 632 million pounds (990 million US dollars) deal.

Kalahari owned $43 \%$ in Extract Resources, whose wholly owned subsidiary, Swakop Uranium, received a mining license to develop Husab. A joint venture between local and Chinese partners announced the start of constructions for the 12 billion Namibian dollars project near Swakopmund towards the end of 2012. Husab as the third largest known uranium deposit in the world, has a 
production potential of 15 million pounds uranium oxide per year. Once operational, it will rank Namibia as the second biggest producer on the world market. Construction at the Husab mine continued largely according to plan, but with complaints about the shortage of qualified workers and no secure long-term solution for water and energy supplies. During November 2015, dissatisfaction among locally employed workers over the employment of large numbers of foreigners (mainly from Ghana and the Philippines) in jobs, which allegedly could be filled by qualified Namibians, erupted into a series of strikes and violent acts against infrastructure. Becoming operational during 2016, it is expected that the production (mainly for Chinese energy consumption and hence not dependent upon world market prices) will to a large extent compensate for the effects caused by a sluggish global economy and offset negative impacts on the mining industry. But securing reliable water and power supply without lasting damages to the natural habitat or at the expense of the ordinary users living in the wider area will continue to pose major obstacles.

\section{Who Gains?}

Collaboration in the area of trade will often have one party gaining and the other losing. This is the case in the trade relation between China and Namibia. This review will set the tone for a comprehensive exploration of the trade activities between these two countries, as it raises some key issues pertaining to some of the contracts and agreements. This review only points out some few indicators reflecting a gain or loss in the relationship and further empirical studies are needed to support these claims. The review makes inferences from the effect the trade relation has had, not directly on the economy, but on secondary parties. The discussion will center on three main actors; the Government of Namibian, the Domestic Construction Sector, and the Domestic Retail and Manufacturing Industry.

\section{The Namibia Government}

The government of Namibia, on the face value, looks like it is gaining from the mutual relationship between these two countries. The Namibian government has found it relatively challenging, since gaining independence, in accessing concessionary loans from international bodies and countries traditionally known to lend to nations. This has been as a result of the country being placed in the category of middle-income nations. This situation is heavily argued by the Namibian government as the country experiences enormous income inequality, a Gini coefficient of approximately 59.7. Sweden, having been a traditional donor to Namibia, for instance, has begun to reduce the amount of assistance given to the country. The Chinese have stepped in as Namibia's "savior", providing what looks like a safer and better option to the long existing traditional donors and this the government of Namibia sees as an opportunity to advance its developmental agenda and the UN Millennium Development Goals. The relationship between these new partners does not seem to have been a bother to successive Namibian government as they receive technical, and financial support for their political agenda.

These benefits are not only limited to the government at the national level, it cascades down to the provinces and municipalities. A respectable number of municipal offices and provinces have entered into agreement with various Chinese provincial governments, cities and firms in the quest of aiding them to deliver an improved economy to their people. Some of the agreements have been between Nantong City and Helao Nafidi, Lanzhou and Tsumeb, Shanghai and Windhoek, and Zhingzhou and Mariental. These pacts are largely aimed at attracting Chinese entrepreneurs and investors from 
these big Chinese cities to these Namibian towns and cities to explore construction, tourism, and other economic opportunities, subsequently leading to employment for the Namibian citizens and an improved economic life. Conversely, some economists in Namibia have expressed their displeasure about the unavailability of a comprehensible policy by the government of Namibian to involve domestic industries in the trade between these two countries. They argue that until the local industry is actively involved in this relationship, trade between these two countries will be limited the exportation of agro products and minerals to China. This review propose a detailed empirical study into this relationship at the governmental level, investigating what the Chinese stand to benefit, it is only then that we can determine which party is actually making gains and which is losing.

\section{The Construction Sector}

According to the Namibia Tender Board, currently, among some of the major construction firms operating in Namibia are China Jiangxe, China State Construction, New Era Investment, China Nanjing International (Namibia) Pty Ltd, and China Zhengtai. These firms' operations in the country have raised a lot of questions among domestic construction firms. The local firms have vehemently voiced out their displeasure about the preferential treatments given to the Chinese firms at the expense of the local firms (Kakujaha-Matundu (2008).

Coupled with the preferential treatments accorded these Chinese firms, unlike the Namibia firms, regulations are relaxed for their operations. The Namibian construction firms are organized under one body, Construction Industries Federation of Namibia (CIF). For their operations, they are expected to meet a number of regulations. Some of the registration process these Namibian construction firms go through are evidence of registration as a Namibian tax payer, a valid affirmative action certificate issued by the Employment Equity Commission, a certificate of good standing from the Social Security Commission and proof of compliance with the Labour Act, which demands a firm should be a party to the collective agreement concluded between CIF and the Metal and Allied Namibian Workers Union (MANWU).

An evidence of the unfair treatments Namibian construction firms face as opposed to their Chinese counterparts is seen in the case between two Namibian firms on one hand, Namibia Construction and Murray and Roberts, and China Nanjing International (Namibia) Pty Ltd, on the other hand. The Namibian Construction firm's Co-Chief Executive Officer asserted;

"Notwithstanding the fact that the Government has threatened and criminally charged various Namibian entities for not complying with the provisions of the Affirmative Action (Employment) Act, it is apparent that (China Nanjing) has been enjoying preferential and unequal treatment vis-à-vis its Namibian counterparts which has now been endorsed by the award of (the Lands Ministry head office tender)." (Tender to Chinese Builder under Attack by Werner Menges, 2007)

As expected, the government of Namibia came out to deny any unfair treatment, indicating the bids submitted by the two Namibian firms were not in alignment with the requirements of the Tender Board. This is just one of the many grievances constantly being expressed by local construction firms, regarding itself as having fallen prey to the presence of Chinese firms in the country. On an affirmative note, small construction firms have gained from the cheap building materials produced by Chinese firms. However, on the whole, the grievance among majority of the construction firms is an indication they are on the losing end. 
INTERNATIONAL JOURNAL OF ACADEMIC RESEARCH IN BUSINESS AND SOCIAL SCIENCES Vol. 10, No. 6, June, 2020, E-ISSN: 2222-6990 @ 2020 HRMARS

\section{The Retail and Manufacturing Sector}

A general concern that has engulfed producers on the African continent is the fear of losing the domestic market to cheap products from China. This is no different from what is prevalent in Namibia. The contribution to GDP by the Namibian manufacturing sector has been relatively low, with the sector contributing $12.5 \%$ to GDP in 2018 . This was largely due to the decline in subsectors as beverages, basic non-ferrous metals processing, fish processing, and meat processing. These subsectors are at the heart of the manufacturing sector; as such a decline sharply affects the performance of the entire sector. Products from the agro sector are the main inputs for the manufacturing industry.

The sector is not heavily affected by the presence of the Chinese, considering a majority of the subsectors are into processing food stuffs into products which are not imported from China. However, the case might be different in the coming years as the government of Namibia puts in place measures to expand the sector. At the same time, this could be an advantage for Namibia, should they direct attention to producing to export to China, considering their ever growing demand for food products.

A general consensus among industry players in the subsectors have indicated in as much as cheap products from China have the probability of affecting the performance of some of the subsectors, so far its negative impact has not been significant. The cheap Chinese products have turned to satisfy the demands of the people at the lower ends of the economic spectrum, while, products manufactured by local Namibian firms, due to their quality and relatively high prices, are patronized by the middle and upper income earners. For instance, sponge mattresses sold by the Chinese are of density 8 (low quality), while Namibian manufacturers offer density 12 (high quality).

Considering the retail sector, Sherbourne in 2005 indicated there were approximately hundred Chinese small retailers in Namibia, however, by the year 2017, approximately 1500 Chinese retails shops have sprung up, with the Chinese ambassador to Namibia noting that there were approximately 7000 Chinese businesses in the country. The retail industry is gradually being occupied by the Chinese, which is a bit worrying. This is one of the industries which should be preserved for the native Namibians, as it does not require a huge amount of capital to begin operating a retail venture. If the current norm is allowed to continue, most of the Namibians without formal education and the low income earners who operate in this sector will be thrown out of business, considering their Chinese counterparts offer relatively cheaper products.

\section{Conclusion}

The conclusion will focus on looking at the performance of the industries that have been reviewed. The performances are largely observed at the macro level. Retail and Wholesale trade contributed $20.1 \%$ and $11.7 \%$ respectively to the gross domestic product, accounting for the highest tertiary sector contribution to GDP in 2015. After recording a growth rate of $7.4 \%$ in 2015 , the sector experienced a decline of $3.4 \%$ in 2016 on the backdrop of decline growth in other sectors with the retail and wholesale sector not being and exception. Quarterly growth estimates shows that wholesale and retail trade sector registered declines of 7.5, 8.2 and 4.4 percent in the first, second and third quarters of 2017 respectively. These declines are attributable to a contraction in the total revenues of wholesale and retail trade due to low demand. Moreover, slower growth was notable in the sales of vehicles and supermarkets particularly in the third quarter of 2017. Considering the growing presence of Chinese shops all over Namibia and the fact that the large number of the over 
INTERNATIONAL JOURNAL OF ACADEMIC RESEARCH IN BUSINESS AND SOCIAL SCIENCES Vol. 10, No. 6, June, 2020, E-ISSN: 2222-6990 @ 2020 HRMARS

6000 Chinese in Namibia engage in some form of retail or wholesale activities, becomes imperative for an empirical study to be conducted, assessing the impact of these retail and wholesale business on the sectorial performance.

Taking a look at the mining industry, some positive developments were detected as noted by Fraser Institute's Investment Attractiveness Index, which is primed by an annual global survey of mining firms. Quarterly analysis indicates that mining and quarrying sector recorded significant growth of 18.7, 25.8 and 11.3 percent in the first, second and third quarters of 2017 respectively, compared with declines in both the first, second and third quarters of 2016. The stronger growth in the mining and quarrying sector during the three quarters of 2017 is attributable to strong growth in most subsectors. Herein, strong growth in the diamond and uranium sub-sectors is attributable to an increase in carats produced and overall increase in production respectively, among others. The question empirical studies ought to focus on now is whether Chinese firms play any role in the strong growth that the mining sector is experiencing. Further issues worth investigating revolve around the exports or processing of these minerals; are they exported to China - considering its dominant role in the sector? What are the details of the agreements surrounding the foreign firms extracting minerals and how does this favor the Namibian?

The construction sector experienced a decline of $7.8 \%$ in 2016 owing to the contraction in construction industry. Quarterly figures indicate that the construction industry has been on a path of contraction for the preceding seven quarters, beginning from the first quarter of 2016. It has continued performing dismally, as it is estimated to have contracted by $44.8,45.9$ and 36.9 percent in the first, second and third quarters of 2017 respectively. Performance in the sector remains subdued, attributable to government expenditure cuts arising as a result of fiscal consolidation measure being pursued, as well as 2016/17 expenditure arrears (unpaid invoices) of N\$2.9 billion among others. Government capital projects which were to drive growth in the construction sector came to a halt in 2016, thereby straining the performance of the sector even more (National Planning Commission, 2018). Aside these governmental factors, wouldn't the dominance of foreign firms in the sector be a factor in the poor performance? The review shows the inroads foreign firms, like those from China, are making in this sector, and it becomes imperative that an empirical study is conducted to ascertain the impact of foreign firms in this sector.

The purpose of the study was to explore the activities of the Chinese within the construction, mining, and retail and wholesale sectors. The study found out that the Chinese are more adaptable to doing Business in Namibia and are dominantly present in all the sectors under study. In the retail sector, most of the products sold by Chinese shops are relatively cheap compared to other shops, as such receives more patronage. On a larger not, the performance of the retail sector has been on the decline in recent years. The mining sector has experienced a significant impact since 2015 and Chinese firms predominantly dominate the sector. Most of the government projects in Namibia are financed and executed solely by the Chinese, contrary to the expectation of Namibian contractors patterning with their Chinese counterparts. Generally, the current review indicates the presence of the Chinese in the selected sectors under study has produced a mixed impact despite their dominance in those sectors.

\section{Theoretical and Practical Contributions}

The presence of the Chinese in Namibia has surged, however, little research has been conducted to ascertain their presence in and impact on some key sectors. Theoretically, the present review has 
INTERNATIONAL JOURNAL OF ACADEMIC RESEARCH IN BUSINESS AND SOCIAL SCIENCES

Vol. 10, No. 6, June, 2020, E-ISSN: 2222-6990 @ 2020 HRMARS

established certain fundamentals upon which an empirical study could be built. Further, previous studies had only explored the impact of Chinese businesses on the economy as a whole; the current review however, breaks the impact down into different sectors. Practical, the government of Namibia and policy makers, based on the findings from this review, can develop policies that reserves petty retail and other businesses solely for its citizens considering the influx of the Chinese in all areas of the economy, especially the retail and wholesale sector.

\section{Acknowledgement}

The authors are grateful to the staff of the school of Economics and Management, Zhejiang University of Science and Technology for their support.

\section{References}

Dobler, G. (2017). China and Namibia, 1990 to 2015: how a new actor changes the dynamics of political economy. Review of African Political Economy, 44(153), 449-465, DOI: 10.1080/03056244.2016.1273828

Gan, Y. (2006). A letter written in response to "More on" Yellow Threat "Debate". Henning Melber. The Namibian, 26 September.

Jauch, H. (2009). Trade unions in Namibia: Defining a new role? Labour Resource and Research Institute (LaRRI). Retrieved from http://www.larri.com.na/research/Trade\%20Unions\%20in\%20Namibia\%20 2004.doc.

Kakololo, E. (2007). Chinese acquire stake in standard bank. New Era, 12 (December), 1.

Kakujaha-Matundu, O., \& Odada J. E. (2008). China-Africa economic relations: The case of Namibia. Windhoek: Department of Economics, University of Namibia,

Menges, W. (2014). Chinese firm loses RA office tender appeal. The Namibian. Retrieved from http://www.namibian.com.na

Menges, W. (2007).Tender to Chinese builder under attack. The Namibian. Retrieved from http://www.namibian.com.na.

Melber, N. (2019). China in Namibia: An "All-Weather-Friendship" examined. Afriche orienti, Melber, 7-23.

Niikondo, A., \& Coetzee, J. (2009). Perceptions on the impact of Chinese businesses in Namibia: A Case Study on the Retail and Construction sector in Windhoek. Windhoek: Monographs Collection/Friedrich- Ebert-Stiftung.

Sasman, C. (2007). Chinese Ambassador says goodbye. New Era, 1(October), 4

Santos, A. A. (2018). Namibia 2018 African economic outlook country note. African Development Bank Group

Sherbourne, R. (2005). Comrades and Capitalists: The growing presence of China in the Namibia economy and its possible economic and political implications. Namibia: Friedrich-EbertStiftung.

NAMP/AFP. (2007). Despite outcry, many Americans cannot live without Chinese goods. New Era, 23(July), 5.

National Planning Commission. (2018). Status of the Namibian economy. Namibia: Office of the President.

Tyitende, R. (2015). An Evaluation of the impact of Chinese involvement in the construction sector in Namibia (Thesis). University of Namibia 
INTERNATIONAL JOURNAL OF ACADEMIC RESEARCH IN BUSINESS AND SOCIAL SCIENCES Vol. 10, No. 6, June, 2020, E-ISSN: 2222-6990 @ 2020 HRMARS

Yan. (2006). China to double 2006 assistance to Africa by 2009. Retrieved from http://www.newsgd.com/news/chinakeyword/focac/ 200611040010.htm. 